Article

\title{
Exploring Farmers' Indigenous Knowledge of Soil Quality and Fertility Management Practices in Selected Farming Communities of the Guinea Savannah Agro-Ecological Zone of Ghana
}

\author{
Richard Ansong Omari ${ }^{1}$, Sonoko Dorothea Bellingrath-Kimura ${ }^{2,3}$, Elsie Sarkodee Addo ${ }^{4}$, \\ Yosei Oikawa ${ }^{4}$ and Yoshiharu Fujii ${ }^{4, *}$ \\ 1 United Graduate School of Agricultural Science, Tokyo University of Agriculture and Technology, \\ Tokyo 183-8509, Japan; talk2jafakingonline@gmail.com \\ 2 Leibniz Centre for Agricultural Landscape Research, 15374 Müencheberg, Germany; belks@zalf.de \\ 3 Institute of Agriculture and Horticulture, Faculty of Life Science, Humboldt-University of Berlin, \\ 14195 Berlin, Germany \\ 4 Institute of Agriculture, Tokyo University of Agriculture and Technology, Tokyo 183-8509, Japan; \\ elsieaddo67@yahoo.com (E.S.A.); yosei@cc.tuat.ac.jp (Y.O.) \\ * Correspondence: yfujii@cc.tuat.ac.jp; Tel.: +81-42-367-5625
}

Received: 5 March 2018; Accepted: 27 March 2018; Published: 30 March 2018

\begin{abstract}
Efforts to improve soil productive capacity aimed at boosting crop production in the Northern Ghana has primarily focused on field-based experiments with little documentation on farmer practice and local indigenous knowledge of soil management. A sample group of 114 farmers from five farming communities in the Guinea Savannah was interviewed to evaluate their indigenous knowledge of crop production practices in the context of soil health, fertilization management, and crop yield. Data were collected using semi-structured interviews and responses for each category were calculated using simple proportions. Farmers' fertilization practice was primarily influenced by fertilization resource availability and crop yield response. The results showed that inorganic fertilization was the commonest fertilization type among farmers. Farmer local indicators of soil health were predominantly limited to visually observable signs such as presence or absence of indicator plants, growth vigor of plants, soil color, and tilth, texture, and compaction. Non-tactile and visible indicators, notably soil chemical composition and presence of soil microorganisms, was rarely used. The listed indicators were congruent with scientific reports, although some knowledge gaps, particularly on the use of indicator plants, were identified. The use of indicator plants as determinants of healthy or non-healthy soils appeared to be influenced by the ease of control of weeds, its utilitarian benefits, benefits to the soil, and threats on cultivated crops. Famers were well informed about the decreasing crop yield. Fertilization practices and limitations in soil management practices with proposed capacity building approaches aimed at enhancing productive capacities of cultivated farmlands are discussed.
\end{abstract}

Keywords: Ghana; Guinea savannah ecological zone; farmer; soil health; soil health indicator; fertilization; indigenous knowledge; Ferric Acrisol/Ferric Lixisol

\section{Introduction}

In recent years, sustainable soil management practices have become a major concern to farmers, researchers, and policymakers in Ghana. This is particularly important in the Guinea Savannah (GS) ecological zone where less productive soils are notably prevalent [1]. The GS covers the widest 
area among the five main ecological zones of Ghana, known for cereal and legume production and rearing of small ruminants [2]. Unit of land per farmer in the region is usually less than 2 hectares [3], characterized by declining yield output [4,5]. This has partly been attributed to the deteriorating soils [6] and unpredictable rainfall conditions [7]. A study by Issaka et al. reported of the low soil nutrient levels in the GS [8], partly due to its continuous use for crop production with little or no proper management schemes. A sustainable soil management strategy involving relevant stakeholders is therefore important in enhancing the productive capacity of soils in the GS zone.

Traditional soil management experience among farmers in Ghana is image driven. Regardless of the impacts of climatic variables on soil degradation, farmers' view and knowledge of soil is a significant production factor [9]. In most cases, in-depth knowledge of soil processes by farmers reflects sound soil management and vice versa. In order to ensure effective policy formulation towards solving problems of soil productivity in the GS, it is important to actively involve farmers in the requisite capacity building programs. Farmers' experience, local knowledge, and indigenous practices are necessary resources that should be developed in combination with scientific knowledge. Such participatory research approach involving farmers are important for the development of technologies and management innovations [10-12]. However, numerous soil productivity enhancement studies in the GS have mainly been on-station trials with little or no feedback on its adoption by farmers. Such studies have principally focused on crop yield and specific soil parameters with limited attention to farmers' local knowledge and their holistic view of the soil.

Soil quality is the capacity of the soil to function as a vital living system to sustain biological productivity, promote environmental quality, and maintain plant and animal health [13]. Good soil management, which integrates the biological, chemical, and physical attributes, usually connote enhanced soil quality [14]. In many cases, there is a direct link between farmers' fertilization practices and the resultant effects on soil quality status [15]. The indicators of soil quality assessment commonly used are largely based on scientific methodologies. Consequently, most of these indicators have been recommended in the literature and tend to override the existing local knowledge among farmers. However, diverse farming practices among farmers in the GS exist and such responses could be adopted into policies for future agricultural innovation development. Hence, an effective collaboration among farmers, scientists, extension agents, and other stakeholders is needed to develop a practical based adaptive soil management technique to improve soil productivity. A practical strategy is to combine the indigenous sustainable land management strategies with already common management practices [16].

To develop the indigenous knowledge of soil management aimed at increasing crop yield output at the community level, a starting point is to understand farmers' thoughts and perception of their current management methods. Thus, this paper attempted to evaluate the state of farmers' knowledge on soil health and crop production practices within the context of fertilization practices, organic residue management, and crop yield in selected farming communities in the GS zone of Ghana.

\section{Materials and Methods}

\subsection{Description of Study Area}

The study was conducted in five farming communities in the GS; Dimabi, Nyankpala, Dindo, Gbulung, and Golinga in the Tolon/Kumbungu district of Ghana (Figure 1). The communities lie within latitude $09^{\circ} 15^{\prime}$ to $25^{\prime} \mathrm{N}$ and longitude $0^{\circ} 52^{\prime}$ to $58^{\prime} \mathrm{W}$ with an altitude ranging between 120 and $200 \mathrm{~m}$. The communities are located on a plain dominated by Ferric Acrisols or Ferric Lixisols soil types [17]. The area has uni-modal mean annual rainfall of about $1100 \mathrm{~mm}$ (Ghana Meteorological Agency, Accra, Ghana) beginning from April through to September. The climate is characterized by unreliable rainfall; flash floods and drought that hugely impacts crop production. Farming activity in the area is heavily dominated by smallholder farmers who mainly grow cereals (maize (Zea mays (L.), sorghum (Sorghum bicolor (L.), and millet (Pennisetum glaucum (L.)), 
legumes (soybeans (Glycine max (L.) Merr.), cowpea (Vigna unguiculata (L.) Walp.), and pigeonpea (Cajanus cajan (L.) Millsp.)), and tuber crops (yam (Dioscorea L.), cassava (Manihot esculenta Crantz)) [2]. A significant proportion of the farmers keep livestock (Cattle, sheep, and goat) generally for meat. Most cultivated farmland soils in the GS ecological zone have shown evidence of declining soil fertility and low organic matter [1]. The main system of farming is purely traditional with little mechanization, which employs the use of hoe and cutlass with labor primarily provided by family members.

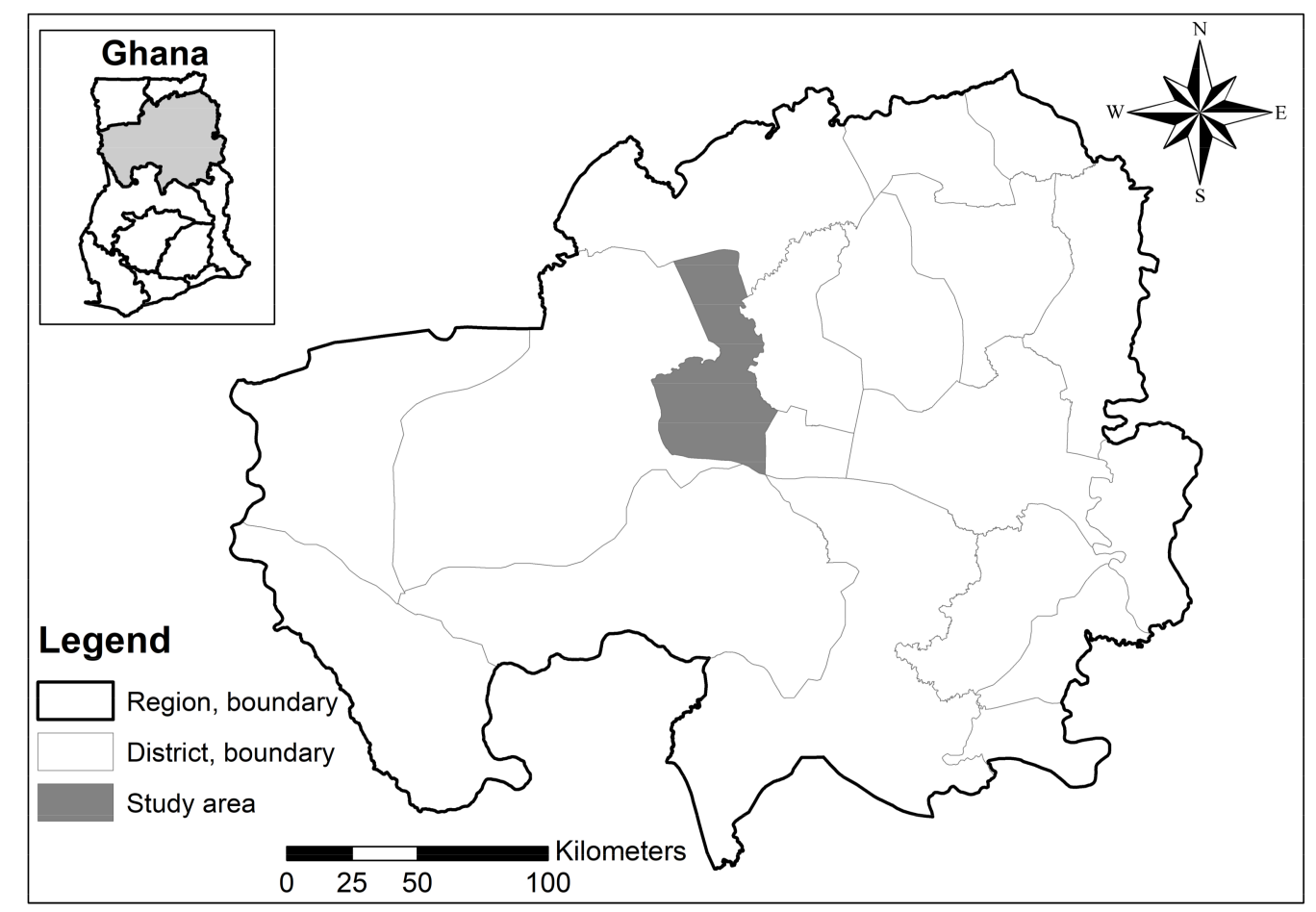

Figure 1. Map of Ghana showing the location of the study site.

\subsection{Data Collection}

A household survey was conducted from February to March 2015, where 114 farmers were selected from five farming communities. Resident government researchers in the district assisted in the identification of the villages and households through key informant interviews and consultations. This study targeted farmers who were active in their crop production process. Face-to-face interviews were conducted using semi-structured questionnaires [18]. The interviews were carried out with the help of interpreters in cases where language barrier existed. The interpreters had previously been briefed about the objectives of the study and were sensitized especially on the key terminologies in the questionnaire. Interviews were conducted in the mornings and during afternoons, which were usually the best times to minimize disruption of farmers' busy schedule. Special care was taken to ensure that the sample size had a significant proportion of women. The questionnaires were first pretested among the key informants and interpreters and necessary changes were effected before administering to each participant. The interview questionnaires were composed of both closed and open-ended questions that explored farmers' perceptions and indigenous knowledge on soil health, fertilization practices, organic residue management, and crop yield in the respective communities. During the survey, it was emphasized that plant as bioindicators of healthy or non-healthy soil means plant species whose dominance on soil connotes a corresponding soil quality and vice versa. 


\subsection{Data Analysis}

The interview data were subjected to basic descriptive analysis using IBM SPSS (version 21, IBM, Armonk, NY, USA). The descriptive statistics tools comprised simple proportion, percentages, and frequencies of all studied variables. Categorical variables were analyzed using cross-tabulations. A two-way Chi-square $\left(x^{2}\right)$ test was used to test the level homogeneity among the categorical variables [19].

\section{Results and Discussion}

\subsection{Demographic Characteristics of Respondents}

Of the 114 respondents, $21.1 \%$ were females and $78.9 \%$ males (Table 1 ). The age of the respondents ranged from 21 to 70 years with an average of 39 years. A significant percentage $(53.8 \%)$ of the respondents was between 24 and 37 age groups. The majority $(66.3 \%)$ of the respondents had no formal education. On the other hand, only $7.7 \%$ had a tertiary education which comprised colleges, vocational/technical and university institutions. Most of the interviewed farmers began farming activity at an early age with varying degrees of experience ranging from 2 to 50 years. Farming is the main source of livelihood in the surveyed communities with over $90 \%$ of the farm sizes between 0.4 and 4.0 hectares. The age distribution, gender, educational background and work experience of the respondents among the communities were not significantly different. This suggests a demographic homogeneity among all the studied communities. For this reason, the five communities were treated as a single population in the subsequent analyses.

\subsection{Farmers' Fertilization Practice}

Over $95 \%$ of the farms had been under cultivation for a minimum of three years (Data not showed). A significant percentage of the respondents, constituted by $48.3 \%$ males and $14.9 \%$ females practiced inorganic fertilization (IF) (Table 2). This predominantly involved the use of nitrogen (N), phosphorus $(p)$ and potassium $(K)$ fertilizers as a basal application with urea or sulphate of ammonia as a top dressing. Of the total respondents, $14.0 \%$ combined the application of inorganic and organic fertilizers, while $7.9 \%$ who were only males applied only organic materials. $14.9 \%$ of the total respondents, which by proportion were predominantly males, applied no fertilizer to their crops. No fertilization comprised crop rotation, land rotation and fallow systems which are usually applicable for farmlands located several kilometers away from farmers' settlements. Regarding the reasons for the choice of IF practice, varied responses were given by farmers. While $36.8 \%$ based their choice on the high crop yield response, $22.4 \%$ used IFs because it was a common practice in the community. While $15.8 \%$ cited less availability of organic materials, $13.2 \%$ used IFs because of its availability. Interestingly, $3.9 \%$ of the respondents used IFs purposely to minimize the negative effects of Striga hermonthica (Delile) Benth.

Among the respondents who practiced no fertilization, a significant proportion $(80 \%)$ indicated the less relevance of fertilization on the yield of cultivated crops. Their crops comprised soybean, groundnut (Arachis hypogaea L.), cowpea, yam and cassava (data not shown). On the other hand, $52.6 \%$ of the organic-based fertilization farmers cited material availability in the communities, $26.3 \%$ because of the general soil conditioning and $18.4 \%$ due to its low cost. The general soil conditioning indicator comprised soil erosion control, drainage and aeration improvement and moisture maintenance. Again, 7.9\% cited the long-term positive effects on the soil while $5.3 \%$ stated its high crop yield response. Male respondents being sole managers of land in the surveyed communities predominantly cultivated cereals i.e., maize, rice and sorghum (Table 3). On the other hand, more females by proportion cultivated legumes and vegetables such as groundnut, ayoyo (Corchorus olitorius L.), tomato (Solanum lycopersicum L.), garden egg (Solanum integrifolium L.), etc. 
Table 1. Chi-square analysis of differences in selected personal and demographic characteristics of respondents.

\begin{tabular}{|c|c|c|c|c|c|c|c|}
\hline \multirow{4}{*}{$\begin{array}{l}\text { Household Demographic } \\
\text { Characteristics }\end{array}$} & \multicolumn{3}{|c|}{ Communities } & \multicolumn{2}{|c|}{$x^{2}$} & \multirow{3}{*}{\multicolumn{2}{|c|}{ Significance among Communities }} \\
\hline & \multirow{3}{*}{$\begin{array}{c}\text { Dindo } \\
\% \text { per Comm }{ }^{(4)} \\
(n=22)\end{array}$} & \multirow{2}{*}{$\begin{array}{c}\text { Dimabi } \\
\% \text { per Comm } \\
\end{array}$} & \multirow{2}{*}{$\begin{array}{c}\text { Nyankpala } \\
\% \text { per Comm }\end{array}$} & \multirow{2}{*}{$\begin{array}{c}\text { Gbulung } \\
\% \text { per Comm }\end{array}$} & \multirow{2}{*}{$\begin{array}{c}\text { Golinga } \\
\% \text { per Comm }\end{array}$} & & \\
\hline & & & & & & & \\
\hline & & $(n=24)$ & $(n=22)$ & $(n=22)$ & $(n=24)$ & & \\
\hline Gender & & & & & & $3.0, \mathrm{df}=4$ & NS \\
\hline Male & 73.7 & 90.9 & 75.0 & 82.1 & 72.7 & $p=0.6$ & \\
\hline Female & 26.3 & 9.1 & 25.0 & 17.9 & 27.3 & & \\
\hline Age group & & & & & & $14.4, \mathrm{df}=12$ & NS \\
\hline $10-23$ & 5.3 & 0.0 & 16.7 & 19.3 & 4.5 & $p=0.3$ & \\
\hline $24-37$ & 52.6 & 54.5 & 58.3 & 53.8 & 50.0 & & \\
\hline $38-50$ & 10.5 & 18.2 & 16.7 & 19.2 & 27.3 & & \\
\hline $51+$ & 31.6 & 27.3 & 8.3 & 7.7 & 18.2 & & \\
\hline Educational background & & & & & & $17.1, \mathrm{df}=16$ & NS \\
\hline None & 78.9 & 40.9 & 66.6 & 76.9 & 68.2 & $p=0.4$ & \\
\hline Primary & 10.5 & 22.7 & 8.3 & 7.7 & 9.1 & & \\
\hline $\mathrm{JHS}^{(1)} / \mathrm{MSLC}^{(2)}$ & 5.3 & 22.7 & 4.2 & 11.5 & 13.6 & & \\
\hline SHS ${ }^{(3)}$ & 5.3 & 4.5 & 4.2 & 0.0 & 0.0 & & \\
\hline Tertiary & 0.0 & 9.2 & 16.7 & 3.9 & 9.1 & & \\
\hline Work experience & & & & & & $8.7, \mathrm{df}=12$ & NS \\
\hline$<5$ years & 18.2 & 16.7 & 13.6 & 18.2 & 12.5 & $p=0.7$ & \\
\hline $5-10$ years & 27.3 & 12.5 & 40.9 & 31.8 & 29.2 & & \\
\hline $11-20$ years & 31.8 & 29.2 & 31.8 & 22.7 & 37.5 & & \\
\hline$>20$ years & 22.7 & 41.7 & 13.7 & 27.3 & 20.8 & & \\
\hline Farm size & & & & & & $18.7, \mathrm{df}=12$ & \\
\hline$<0.4$ ha & 31.8 & 16.7 & 13.6 & 40.9 & 33.3 & $p=0.09$ & * \\
\hline $0.4-0.8$ ha & 18.2 & 37.5 & 40.9 & 36.4 & 45.8 & & \\
\hline $0.8-2.0$ ha & 40.9 & 29.2 & 36.4 & 22.7 & 4.2 & & \\
\hline$>2.0$ ha & 9.1 & 16.6 & 9.1 & 0.0 & 16.7 & & \\
\hline
\end{tabular}

(1) JHS = Junior High School; ${ }^{(2)}$ MSLC = Middle School Leaving Certificate; ${ }^{(3)}$ SHS = Senior High School; ${ }^{(4)}$ comm $=$ Community. NS and ${ }^{*}$ indicate non-significance and significance at $\alpha=0.10$, respectively. 
Table 2. Farmers' fertilization practice.

\begin{tabular}{|c|c|c|c|c|}
\hline \multirow{2}{*}{$\frac{\text { Parameter }}{\text { Type of Fertilization Practice in the Farm }}$} & \multicolumn{4}{|c|}{ (\% of Respondents) } \\
\hline & Inorganic & Combine & Organic & No Fertilization \\
\hline Male & 48.3 & 9.6 & 7.9 & 13.2 \\
\hline Female & 14.9 & 4.4 & 0.0 & 1.7 \\
\hline Total & 63.2 & 14.0 & 7.9 & 14.9 \\
\hline Reasons for choosing inorganic fertilization & \multicolumn{4}{|c|}{$(\%$ of respondents $) *$} \\
\hline High crop response \& readily available $\mathrm{N}$ & \multicolumn{4}{|c|}{36.8} \\
\hline Common practice & \multicolumn{4}{|c|}{22.4} \\
\hline Less available organic materials & \multicolumn{4}{|c|}{15.8} \\
\hline Readily available fertilizer in the market & \multicolumn{4}{|c|}{13.2} \\
\hline Easy to apply and use & \multicolumn{4}{|c|}{9.2} \\
\hline Effective in controlling Striga & \multicolumn{4}{|c|}{3.9} \\
\hline Low knowledge in handling organics & \multicolumn{4}{|c|}{2.6} \\
\hline Reasons for adopting no fertilization & \multicolumn{4}{|c|}{ (\% of respondents) } \\
\hline Cultivated crops do not need fertilizer & \multicolumn{4}{|c|}{80} \\
\hline High cost of fertilizers & \multicolumn{4}{|c|}{20} \\
\hline Reasons for adopting organic fertilization & \multicolumn{4}{|c|}{ (\% of organic-based respondents) ${ }^{*}$} \\
\hline Availability in the community & \multicolumn{4}{|c|}{52.6} \\
\hline General soil conditioning & \multicolumn{4}{|c|}{26.3} \\
\hline Low cost & \multicolumn{4}{|c|}{18.4} \\
\hline Long term effects & \multicolumn{4}{|c|}{7.9} \\
\hline Crop response & \multicolumn{4}{|c|}{5.3} \\
\hline
\end{tabular}

Inorganic; NPK, Urea, Sulphate of ammonia, organic; Compost, crop residues, weed litter cattle, sheep, goat \& chicken manure, combine; Organic and inorganic, no fertilization; crop rotation, land rotation, and fallow systems. Frequencies are proportions (\%) of farmers' response to a given practice alone. * Percentages add up to more than $100 \%$ because of multiple responses.

Table 3. Cross-tabulation by gender of cultivated crops among the respondents.

\begin{tabular}{ccccc}
\hline \multirow{2}{*}{ Gender } & \multicolumn{3}{c}{ Crop (Frequency) } & \multirow{2}{*}{ Total } \\
\cline { 2 - 4 } & Cereals & Tubers & Legumes \& Vegetables & \\
\hline Male & 59 & 9 & 11 & 79 \\
Female & 17 & 5 & 13 & 35 \\
Total & 76 & 14 & 24 & 114 \\
\hline
\end{tabular}

Frequencies are proportions (\%) of farmers' response. Cereals; maize, rice, millet, sorghum; Tubers; yam and cassava; Legumes and vegetables; groundnut, garden egg, ayoyo.

The results of this study are similar to those of Chianu and Tsujii [20], who reported that significant percentage of farmers in the Savannah region of Nigeria used IFs. In contrast, the use of IFs on bush farming farmlands in the Upper West Region of Ghana (Guinea to Sudan savannah) is practically non-existent except in cereal cultivation particularly maize [21]. Chianu and Tsujii [20] argued that adoption of IF in Nigeria was driven by farmers' high educational background. In the present study, farmers' choice of IFs over the other fertilization practices stemmed from its high crop response, accessibility, and the fact of it being a common practice in the communities. Throughout Ghana, agrochemicals are available in authorized retail outlets or could be obtained from government or non-governmental agencies for free or at subsidized prices [22,23]. Consequently, its use among farmers in the northern Ghana is gaining popularity [1]. However, farmers' rate of fertilizer application is considerably below the recommendations for optimal crop yield [21,24]. Farmers' interest in quick crop response connotes high crop yield relative to soil productivity improvement. This viewpoint characterizes the orientation of many farmers on agricultural production.

Natural fallow system, where less fertile lands are allowed to rest for several years without cultivation has in the past dominated soil fertility improvement approaches in Ghana [1]. In the present study, over $95 \%$ of the farmers' field was continuously cropped. In addition, among the $14.9 \%$ farmers who applied no fertilizer inputs, only a small proportion left their fields to fallow (Table 2). Hence, the preference of IF by farmers over the other fertilization methods, suggests a gradual decrease in the traditional fallow period. As reported by Braimoh and Vlek [25], adoption of high-yielding 
varieties by farmers in Ghana triggered the use of IFs, as a result of the fact that high-yielding varieties tend to require more nutrients.

The present study differed from the findings of Dawoe et al. [10]. According to their study, a significant percentage of farmers in the Atwima Nwabiagya District of Ghana (moist deciduous zone) relied mostly on organic inputs from plants (tree litter, weeds, and crop residues) for fertilization. Accordingly, farmers exhibited high knowledge of soil organic matter (SOM) as the driving force for soil productivity maintenance. Thus, the majority of the farmers employed SOM retention strategies such as slash and mulch, no burning, and crop residue addition. Nevertheless, population pressures and the attendant human activities, harmattan condition (dry climate characterized by dusty wind) and less awareness have driven severe burning of farmlands in the GS zone $[5,26]$.

There is the interplay of farmers' status in the household, gender, and cultivated crop on the type of fertilization being adopted (Tables 2 and 3). As emphasized by the respondents, the entire household led by the man draw resources together in the form of labor towards the production of the main staple food during the rainy season. Such staple foods are usually insured through fertilization to attain high yield; hence a reduction in food shortage threat during the dry season. On the other hand, small-sized marginal lands are allocated to the women for the production of non-staple foods (Table 3). Consequently, such different land use strategies partly contribute to the wide soil fertility variability within farmlands in the same community.

\subsection{Farmers' Perception of Organic Residue Availability and Management}

A significant proportion of farmers (62.5\%) indicated that organic materials were less available in their communities (Table 4) although Issaka et al. [8] assert that organic materials abound in the GS. As shown before, farmers who practice sole organic fertilization adopted the practice mainly due to organic resource input availability (Table 2). This suggests that farmers' decision on organic material availability may be influenced by the use given to the particular organic resource in the locality. The relative importance of each organic residue varies geographically [27], as exhibited at the community level and household units. Traditionally in the surveyed communities, farmers keep farm animals, thus depend on specific organic residues as fodder and bedding material for their livestock [28,29]. Moreover, many farmers still stick to the use of grasses for roofing, fuel and as mats in the Savannah. This competitive use of plant organic sources as affirmed by $58.1 \%$ of farmers practicing organic fertilization suggests the need for further studies on non-competitive organic resources as potential soil amendments at farm or community level.

A majority (71.7\%) of the interviewed farmers indicated that organic resources were underutilized in their respective communities (Table 4). Again, the general soil conditioning of organic amendment is a notable reason for organic fertilization (Table 2). However, this information was not consistent with some farmer adopted management practices. For example, although the notable proportion of farmers $(17 \%)$ to this survey plough on-field crop residues evenly into the soil after harvest to prevent bushfires, $19 \%$ consciously burn their farms as a land preparation tool prior to planting (Table 4). Moreover, farmers' limited knowledge on organic material management as affirmed by $78.1 \%$ of the respondents was especially evident in the method-, timing- and rate- of material application. A significant percentage (55\%) of farmers leave crop residues as mulch after harvest and such materials subsequently fuel the bush burning activities during the harmattan season. In addition, the results showed that over $60 \%$ farmers apply organic materials twice in a single growing season. This application is undertaken during the initial growing stage of crops (first application) and after harvesting when materials are left on the field (second application). However, several successful studies on soil organic material amendment have focused on the one-time application, usually at the beginning of the growing season [30-33], because of its availability and the extended time required to mineralize in the soil. Regarding the rate of application, the common practice among farmers was to apply any quantity available with less emphasis on the rate of application. However, there are several reports on the influence of organic material per unit area of land and biochemical quality composition on $\mathrm{N}$ 
mineralization and subsequent crop yield returns [34-37]. It can be concluded that to succeed in the use of organic materials as soil fertilizing inputs, two conditions are necessary; (i) organic resource availability and (ii) adequate knowledge on effective organic residue management. This study suggests the need for appropriate sensitization of farmers through various capacity building activities such as field days, seminars, practical training aimed at addressing the limited knowledge on organic residue management.

Table 4. Farmers' perception of organic residue availability and management.

\begin{tabular}{lcc}
\hline \multicolumn{1}{c}{ Parameter } & (\% of Respondents) \\
\hline Are you knowledgeable in organic residue management & Yes & No \\
\hline Male & 18.4 & 60.6 \\
Female & 31.5 & 78.1 \\
Total & (\% of respondents) \\
\hline Availability of organic materials in the community & 62.5 \\
\hline No & 37.5 \\
Yes & (\% of organic-based respondents) \\
\hline Organic materials mostly used & 58.1 \\
\hline Plant sources & 32.3 \\
Animal sources & 9.7 \\
Both & (\% of respondents) \\
\hline Times of application & 60.4 \\
\hline Twice & 35.6 \\
Once & 3.0 \\
Thrice & 1.0 \\
\hline How plans & (\% of respondents) * \\
\hline Mulch & 55.3 \\
Burn & 19.1 \\
Ploughed to decompose & 17.1 \\
Firewood and fuel & 4.3 \\
Fodder & 4.3 \\
Disposed of as garbage & 4.3 \\
\hline Are there organic plants materials in your village that are underutilized & 4.2 \\
\hline No & (\% of respondents) \\
Yes & 71.7 \\
\hline Frequen & 28.3 \\
\hline
\end{tabular}

Frequencies are proportions (\%) of farmers' response to a given practice alone. ${ }^{*}$ Percentages add up to more than $100 \%$ because of multiple responses.

\subsection{Farmers' Perception and Indigenous Indicators of Soil Health}

Majority of the interviewed respondents showed a fairly good knowledge base and understanding of soil health and its effects on the productivity of crops in diverse ways as reflected in their responses (Table 5). In contrast, $42.1 \%$ indicated no knowledge of soil health and its locally identifiable indicators. Farmers predominantly used the presence or absence of a particular weed or plant species as an indicator of a healthy or non-healthy soil. The use of plant species as bioindicators in predicting certain soil properties have been documented in other preceding studies [11,38-40]. In this study, farmers' knowledge of healthy soil in terms of the presence or absence of weed indicators is broadly limited to its ease of management, utilitarian benefits, benefits to the soil and threats on cultivated crops (Table 6). For example, soils that are dominated by Sida acuta Burm. $f$. (palatable fodder), Andropogon gayanus Kunth (palatable fodder), Imperata cylindrical (L.) (good roofing material), and Crotalaria retusa (L.) (green manure) were denoted healthy. Similarly, the majority of farmers listed the presence of $S$. hermonthica, a noxious parasitic weed of cereals [41,42], as an indicator of non-healthy soils. This is most likely due to the devastating effects of S. hermonthica in the GS, where staple foods such as maize, sorghum, millet and upland rice (Oryza sativa (L.) are cultivated. Consistent with Dawoe et al. [10], a sizable proportion (18.2\%) of farmers linked the vigorous growth of weeds to healthy soils. Accordingly, sites with deep green-leaf color ubiquitous weeds were categorized as healthy while those with pale-leaved plants were denoted 
poor-quality land. This vigorous growth and dominance of some plants, which is a function of its increased competitive ability, have strongly been linked to their allelopathic potentials $[43,44]$. Hence, farmers' choice of certain indicator plants of soil health may be due to their allelochemicals which reduce the species diversity and population of other neighboring plants. For example, I. cylindrica, Rottboellia cochinchinensis (Lour.), Commelina benghalensis (L.), Centrosema pubescens Benth. and Hyptis suaveolens (L.) Poit. have been reported to show growth inhibitory effects on other weed species [45-47]. Common weed species whose dominance signifies healthy or non-healthy soils according to the farmers have been summarized in Table 6 .

Table 5. Farmers' indigenous knowledge on soil health.

\begin{tabular}{lcc}
\hline \multicolumn{1}{c}{ Parameter } & (\% of respondents) \\
\hline Are you knowledgeable on soil health indicators & Yes & No \\
\hline Male & 50.9 & 28.1 \\
Female & 7.0 & 14.0 \\
\hline Total & 57.9 & 42.1 \\
\hline Indicators employed in assessing soil health & \multicolumn{2}{c}{ (\% of respondents) $^{*}$} \\
\hline Presence or absence of weed species & 61.0 \\
Color & 55.8 \\
Soil tilth & 18.2 \\
Growth vigor of weeds or crops & 18.2 \\
Crop yield & 11.7 \\
Soil texture & 11.7 \\
Soil compaction & 10.4 \\
Presence of soil organisms & 2.6 \\
Soil fertility & 2.6 \\
\hline
\end{tabular}

Frequencies are proportions (\%) of farmers' response to a given practice alone. * Percentages add up to more than $100 \%$ because of multiple responses.

Although farmers' decision on certain indicator plants of healthy soils possessed little scientific backing (Table 5), a direct correspondence could be deduced from the proposition by Barrios and Trejo [40] and Paniagua et al. [48]. Their study proposed the following parameters to be considered as indicators of a healthy or non-healthy soil determination; growth and vigor of abundant plant species, the presence of native species, and natural succession by native species in regenerative fields. In this study, Icacina oliviformis A. Juss., A. gayanus, and Panicum maximum Jacq. listed as indicators of healthy soils are native species of the Savannah [49-51]. Moreover, C. benghalensis, S. acuta, and A. gayanus are reported to exhibit steady growth in less favorable environments [52-54]. Similarly, $R$. cochinchinensis and $C$. benghalensis are reported to be abundant and tend to dominate fallow fields $[54,55]$. 
Table 6. Summary of weed species whose dominance on farmlands are indicators of healthy soil.

\begin{tabular}{|c|c|c|c|c|}
\hline Common/Local Name & Scientific Name & Family & Desirable Attributes & Category \\
\hline Sida & Sida acuta & Malvaceae & Palatable, easy to control, medicine for curing ailment & Healthy soil \\
\hline Pirima (Gamba grass) & Andropogon gayanus & Poaceae & Grows on infertile soil, palatable for livestock, fire resistant, mulch, ability to store water & Healthy soil \\
\hline Crotalaria (Devil bean) & Crotalaria retusa & Fabaceae & Add nutrient to the soil, fire resistant, easy to control & Healthy soil \\
\hline Spear grass & Imperata cylindrica & Poaceae & As a roofing material, mulch, fire resistant & Healthy soil \\
\hline Yinyang (Itch grass) & Rottboellia cochinchinensis & Poaceae & As fodder & Healthy soil \\
\hline False yam (Takwara) & Icacina oliviformis & Icacinaceae & As mulch, fire resistant & Healthy soil \\
\hline Dungumam & Hyptis suaveolens & Lamiaceae & Medicinal, easy to control & Healthy soil \\
\hline Fulinfugu & Commelina benghalensis & Commelinaceae & Palatable, medicinal & Healthy soil \\
\hline Centro & Centrosema pubescens & Fabaceae & Adds nutrient to the soil, easy to control, as mulch & Healthy soil \\
\hline Guinea grass & Panicum maximum & Poaceae & As fodder, fire resistant & Healthy soil \\
\hline \multirow[t]{2}{*}{ Linlirma } & Ipomoea triloba & Convolvulaceae & Mulch, easy to control & Healthy soil \\
\hline & & & Undesirable Attributes & \\
\hline Woblem & Striga hermonthica & Scrophulariaceae & Difficult to control, reduces crop yield & Non-healthy soil \\
\hline Kponkpongor & Digitaria horizontalis & Poaceae & Difficult to control, seeds contaminate cultivated cereals & Non-healthy soil \\
\hline Sedge & Cyperus rotundus & Cyperacea & Difficult to control, nut destroys cultivated tubers & Non-healthy soil \\
\hline
\end{tabular}


There is, however, conflicting information on farmers' decision on certain plants as indicators of healthy soil. For example, S. acuta, A. gayanus and C. benghalensis listed as indicators of healthy soil in the present study agrees with previous studies [56-58]. Similarly, Digitaria spp. has previously been reported to be associated with non-productive fields in the tropics $[11,59,60]$. In this study, however, farmers identified fields dominated by $S$. acuta to be healthy although it was previously reported as a dominant species in non-healthy wetlands [52]. Nonetheless, species under the genus Andropogon, Imperata and Rottboellia being undesirable and low soil fertility indicators $[11,40,55]$ were identified by farmers of the present study as indicators of healthy soils. One reason for such variant views can be due to the differences in the study locations, as affected by peculiar climatic conditions which influence the evolution of weed species and its subsequent effects on the soil. Again, plants are functionally linked to entire assemblages of below-ground species since plants and soil organisms have co-evolved [61]. A direct evidence of below-ground microbial taxonomical diversity as a prerequisite for functional efficiency is required $[62,63]$. Thus, further studies on soil biology and physico-chemical parameters are needed to understand the mechanisms underlying the complex interactions between the below and above-ground biodiversity.

In the present study, soil characteristic indicators used by farmers to perceive soil health comprised mainly color $(55.8 \%)$, tilth $(18.2 \%)$, texture $(11.7 \%)$, compaction $(10.4 \%)$, nutrient composition $(2.6 \%)$ and soil organisms (2.6\%) (Table 5). Generally, most of the farmers indicated that dark-colored (black) soil signifies healthy soil due to its high SOM contents while pale (red) or white soils were denoted non-healthy. This perception is similar among farmers in Nepal [64]; Suriname [11,65]; and in southern Ghana [10], where dark or black color was associated with fertile soils. Majority of the farmers could explain that the dark color developed from the plant or animal residue additions to soils. Additionally, notable features such as "loose when stepped on", easy to be dug out during harvesting of tubers and moist outlook were used to describe a good soil tilth, as opposed to hard and bare soil with less vegetative cover characterizing non-healthy soils. Farmers' knowledge of SOM effects on soil was mostly linked to soil tilth and activity of "tiny animals" (microbes). This supports an observation by Barrios et al. [59], that a single indicator by farmers usually comprises an integration of multiple aspects of soil quality. Despite farmers' awareness of SOM on soil quality improvement, maintenance of SOM in practice was less common among farmers, as close to $20 \%$ of the visited farms had been subjected to severe burning, substantiating the menace of wildfire in northern Ghana $[15,26]$.

The study findings correspond to Desbiez et al. [11]. According to their study, farmers' indigenous indicators of soil health comprised (i) Biological indicators: plants (other than cultivated crops) and soil fauna whose presence or growth indicates a healthy or non-healthy soil; (ii) Soil characteristic indicators: soil properties which signify the health status of soils; and (iii) Above ground plant vigor: crop or weed-growth characteristics and yield. Healthy soils comprise the integration of physical, chemical and biological components that requires holistic management approaches aimed at optimizing the multiple functions of soil [14]. Farmers' indicators according to this study are generally limited to visible and tactile properties of the soil such as color and tilth, similar to [10,59] in southern Ghana and eastern Africa respectively, and hence could provide a limited assessment of soil health status. Therefore, information transfer through the agricultural extension service on easy farmer friendly approaches on a holistic assessment of soil is needed to bridge the existing knowledge gap among farmers [66]. This calls for expanded research on community- or agro-ecological zone-based specific adaptable methodologies for assessing soils.

\subsection{Perception of Crop Yield}

A large proportion (83.3\%) of respondents to this survey acknowledged their awareness of changes in crop yield in the last ten years (Table 7 ). Of the $83.3 \%, 63.1 \%$ were males while $20.2 \%$ were females. With regards to the trends in yield, $39.5 \%$ of the respondents indicated a decreasing crop yield. However, $37.7 \%$ rather observed an increasing yield while $10.5 \%$ thought crop yield remained the same. The most frequently mentioned reasons for decreasing crop yield were rainfall failure (41.1\%), low soil 
nutrients $(34.3 \%)$, diseases / pest infestation $(12.0 \%)$, and low yielding varieties $(9.8 \%)$. The impacts of unpredicted or erratic rainfall were clearly known by farmers due to their dependence on only natural rainfall for irrigation. However, as reported by Fosu-Mensah et al. [67], the majority of farmers in Sekyedumase district in the southern part of Ghana subjected crop yield decline to climate change, weeds incidence and pest infestation, and disease outbreak. Farmers stated that surface runoff $(53.2 \%)$, continuous cultivation practices $(37.3 \%)$, low fertilizer application rates $(29.2 \%)$ and burning $(12.3 \%)$ were the notable reasons for the low soil nutrients contents (Table 7). According to the respondents, the continuous cultivation practices which trigger soil surface runoff are inevitable due to increasing population in each community making land less available for agricultural production. Continuous cultivation practice due to population pressures coupled with low fertilizer use in Ghana, (as low as $8 \mathrm{~kg} \mathrm{ha}^{-1}$ ) [68] and particularly in GS mainly due to its high cost have rendered many farmlands in the savannah poor. Hence, the resulting declines in crop yield.

Table 7. Farmers' perception of crop yield trend.

\begin{tabular}{lcc}
\hline \multicolumn{1}{c}{ Parameter } & (\% of Respondents) & No \\
\hline Awareness of changes in crop yield & 63.1 & 15.8 \\
\hline Male & 20.2 & 0.9 \\
Female & 83.3 & 16.7 \\
Total & (\% of respondents) \\
\hline If yes, what is the trend in the last 10 years & 39.5 \\
\hline Decreasing & 37.7 \\
Increasing & 10.5 \\
Same & 12.3 \\
Not sure/varies & (\% of respondents) \\
\hline Perceived reasons for the decreasing crop yield & 41.1 \\
\hline Rainfall failure & 34.3 \\
Soil degradation related problems & 12.0 \\
Weed/diseases/pest infestation & 9.8 \\
Low yielding varieties & 3.5 \\
Others & (\% of respondents) * \\
\hline Reasons for low soil nutrients & 53.2 \\
\hline Soil erosion & 37.3 \\
Continuous cultivation & 29.2 \\
Low fertilizer/manure application rates & 12.3 \\
Burning & \\
\hline rencies are proportions (\%) of farmers' response to a given practice alone. * Percentages add up to more than
\end{tabular}

\section{Conclusions}

This study identified soil nutrient management options and its prospects among five farming communities in the GS ecological zone of Ghana. It highlights the key points of farmers' perceived knowledge of organic residue management practices, soil health indicators, and crop yield trends. The study findings reveal that farmers are equipped with some local knowledge that agrees with classical methodologies of identifying healthy soils. Gender is connected to farmers' choice of cultivated crops and fertilization type. Also, sole application of IFs coupled with its low application rates is not enough to deal with the declining crop yield trend and the resultant low soil nutrients in GS. Additionally, know-how on soil and organic material management among farmers are low. From the above observations, this study proposes the following recommendations.

1. Sensitization of farmers through training programs on management of site-specific on-farm organic resources (weeds, crop residues). This must incorporate local knowledge to increase awareness in order to enhance its adoption among farmers.

2. The co-application of IFs with available plant resources should be encouraged. Success in soil health enhancement and the subsequent crop yield improvement will depend on specific on-site 
organic materials, its quality characteristics and the best timings where they can be incorporated into the production cycle.

3. Increased participatory approach targeting a healthy collaboration among farmers, scientists, and other stakeholders is necessary. This will offer the opportunity to examine farmers' indigenous knowledge for the subsequent integration with the scientific knowledge. Evaluation of material quality characteristics of soil health indicator plants by farmers as well as the corresponding soil health condition of the sampling sites would be necessary for future studies on sustainable soil management.

Acknowledgments: The first author is grateful to the Ministry of Education, Culture, Sports, Science and Technology (MEXT), Japan for the financial assistance for his doctoral program. Funding for this study was provided by the Japan Society for the Promotion of Science (JSPS) KAKENHI, Grant Number 26304024. The authors are grateful to Alex Yeboah and Edem Halolo both with the Savannah Agriculture Research Institute-Tamale for their assistance in administering the questionnaires.

Author Contributions: Richard Ansong Omari conceived, designed, performed experiment, analyzed data and wrote the article; Elsie Sarkodee Addo and Yosei Oikawa assisted in the conception, design, and drafting of the manuscript; Yoshiharu Fujii and Sonoko Dorothea Bellingrath-Kimura coordinated the study from its conception to publication.

Conflicts of Interest: The authors declare no conflict of interest.

\section{References}

1. Wood, T.N. Agricultural Development in the Northern Savannah of Ghana. Ph.D. Thesis, University of Nebraska-Lincoln, Lincoln, NE, USA, 2013.

2. Ministry of Food and Agriculture. Agriculture in Ghana, Facts, and Figures; Statistics, Research and Information Directorate (SRID): Accra, Ghana, 2012.

3. Etwire, P.M.; Al-Hassan, R.M.; Kuwornu, J.K.M.; Osei-Owusu, Y. Application of Livelihood Vulnerability Index in Assessing Vulnerability to Climate Change and Variability in Northern Ghana. J. Environ. Earth Sci. 2013, 3, 157-170.

4. Braimoh, A.K.; Vlek, P.L.G. Soil quality and other factors influencing maize yield in northern Ghana. Soil Use Manag. 2006, 22, 165-171. [CrossRef]

5. Kugbe, J.; Fosu, M.; Vlek, P.L.G. Impact of season, fuel load and vegetation cover on fire mediated nutrient losses across savanna agro-ecosystems: The case of northern Ghana. Nutr. Cycl. Agroecosyst. 2015, 102, 113-136. [CrossRef]

6. Nkegbe, P.K.; Shankar, B.; Ceddia, G.M. Smallholder Adoption of Soil and Water Conservation Practices in Northern Ghana. J. Agric. Sci. Technol. 2012, B, 595-605.

7. Kugbe, X.J.; Issahaku, Z. Effects of soil conservation technologies in improving soil productivity in northern Ghana. J. Soil Sci. Environ. Manag. 2015, 6, 158-167.

8. Issaka, N.R.; Mohammed, M.; Tobita, S.; Nakamura, S.; Owusu-Adjei, E. Indigenous fertilizing materials to enhance soil productivity in Ghana. In Soil Fertility Improvement and Integrated Nutrient Management-A Global Perspective; Whalen, K.J., Ed.; InTech: Rijeka, Croatia, 2012; pp. 119-134.

9. Winter, M. New Policies and New Skills: Agricultural Change and Technology Transfer. Sociol. Ruralis 1997, 37, 363-381. [CrossRef]

10. Dawoe, E.K.; Quashie-Sam, J.; Isaac, M.E.; Oppong, S.K. Exploring farmers' local knowledge and perceptions of soil fertility and management in the Ashanti Region of Ghana. Geoderma 2012, 179-180, 96-103. [CrossRef]

11. Desbiez, A.; Matthews, R.; Tripathi, B.; Ellis-Jones, J. Perceptions and assessment of soil fertility by farmers in the mid-hills of Nepal. Agric. Ecosyst. Environ. 2004, 103, 191-206. [CrossRef]

12. Niemeijer, D.; Mazzucato, V. Moving beyond indigenous soil taxonomies: Local theories of soils for sustainable development. Geoderma 2003, 111, 403-424. [CrossRef]

13. Doran, J.W.; Zeiss, M.R. Soil health and sustainibility: Managing the biotic component of soil quality. Appl. Soil Ecol. 2000, 15, 3-11. [CrossRef]

14. Doran, J.; Parkin, T. Defining and assessing soil quality. In Defining Soil Quality for a Sustainable Environment; Coleman, D.C., Bezdicek, D.F., Stewart, B.A.E., Eds.; Soil Science Society of America: Madison, WI, USA, 1994; Volume 35, pp. 3-21. 
15. Omari, R.; Sarkodee-Addo, E.; Fujii, Y.; Oikawa, Y.; Bellingrath-Kimura, S. Impacts of Fertilization Type on Soil Microbial Biomass and Nutrient Availability in Two Agroecological Zones of Ghana. Agronomy 2017, 7, 55. [CrossRef]

16. Winklerprins, A.M.G.A. Local soil knowledge: A tool for sustainable land management. Soc. Nat. Resour. 1999, 12, 151-161. [CrossRef]

17. FAO/ISRIC/ISSS. World Reference Base for Soil Resources (WRB); World Soil Resources Report No. 84; Food and Agriculture Organization of the United Nations: Rome, Italy, 1998.

18. Kelley, K.; Clark, B.; Brown, V.; Sitzia, J. Good practice in the conduct and reporting of survey research. Int. J. Qual. Heal. Care 2003, 15, 261-266. [CrossRef]

19. Gomez, K.A.; Gomez, A.A. Statistical Procedures for Agricultural Research; An International Rice Research Institute Book, A Wiley-Interscience Publication; John Wiley \& Sons: Hoboken, NJ, USA, 1984.

20. Chianu, J.N.; Tsujii, H. Determinants of farmers decision to adopt or not adopt inorganic fertilizer in the savannas of northern Nigeria. Nutr. Cycl. Agroecosyst. 2005, 70, 293-301. [CrossRef]

21. González-Estrada, E.; Rodriguez, L.C.; Walen, V.K.; Naab, J.B.; Koo, J.; Jones, J.W.; Herrero, M.; Thornton, P.K. Carbon sequestration and farm income in West Africa: Identifying best management practices for smallholder agricultural systems in northern Ghana. Ecol. Econ. 2008, 67, 492-502. [CrossRef]

22. Fuentes, P.; Bumb, B.; Johnson, M. Improving Fertilizer Markets in West Africa:The Fertilizer Supply Chain in Ghana; International Fertilizer Development Center (IFDC): Muscle Shoals, AL, USA; International Food Policy Research Institute (IFPRI): Washington, DC, USA, 2012.

23. Benin, S.; Johnson, M.; Abokyi, E.; Ahorbo, G.; Jimah, K.; Nasser, G.; Owusu, V.; Taabazuing, J.; Tenga, A. Revisiting Agricultural Input and Farm Support Subsidies in Africa: The Case of Ghana's Mechanization, Fertilizer, Block Farms, and Marketing Programs; International Food Policy Research Institute (IFPRI) Discussion Paper 01300; IFPRI: Washington, DC, USA, 2013.

24. Jebuni, C.; Seini, W. Agricultural Input Policies under Structural Adjustment: Their Distributional Implications; Working Paper No. 31; Cornell University Food and Nutrition Policy Program: Ithaca, NY, USA, 1992.

25. Braimoh, A.K.; Vlek, P.L.G. Land-cover change trajectories in northern Ghana. Environ. Manag. 2005, 36, 356-373. [CrossRef] [PubMed]

26. Apusigah, A.A. Promoting sustainable wildfire management in Northern Ghana: Learning from history. Eur. J. Soc. Sci. 2007, 5, 61-76.

27. Erenstein, O. Crop residue mulching in tropical and semi-tropical countries: An evaluation of residue availability and other technological implications. Soil Tillage Res. 2002, 67, 115-133. [CrossRef]

28. Agyare, W.A.; Kombiok, J.M.; Karbo, N.; Larbi, A. Management of pigeon pea in short fallows for crop-livestock production systems in the Guinea savanna zone of northern Ghana. Agrofor. Syst. 2002, 54, 197-202. [CrossRef]

29. Ansah, T.; Nagbila, D.A. Utilization of local trees and shrubs for sustainable livestock production in the Talensi-Nabdam District of the Upper East Region of Ghana. Livest. Res. Rural Dev. 2011, 23, 1-6.

30. Chivenge, P.; Vanlauwe, B.; Gentile, R.; Six, J. Organic resource quality influences short-term aggregate dynamics and soil organic carbon and nitrogen accumulation. Soil Biol. Biochem. 2011, 43, 657-666. [CrossRef]

31. Omari, R.A.; Aung, H.P.; Hou, M.; Yokoyama, T.; Onwona-Agyeman, S.; Oikawa, Y.; Fujii, Y.; Bellingrath-Kimura, S.D. Influence of Different Plant Materials in Combination with Chicken Manure on Soil Carbon and Nitrogen Contents and Vegetable Yield. Pedosphere 2016, 26, 510-521. [CrossRef]

32. Yang, N.; Wang, Z.; Gao, Y.; Zhao, H.; Li, K.; Li, F.; Malhi, S.S. Effects of planting soybean in summer fallow on wheat grain yield, total $\mathrm{N}$ and $\mathrm{Zn}$ in grain and available $\mathrm{N}$ and $\mathrm{Zn}$ in soil on the Loess Plateau of China. Eur. J. Agron. 2014, 58, 63-72. [CrossRef]

33. Chivenge, P.; Vanlauwe, B.; Gentile, R.; Wangechi, H.; Mugendi, D.; van Kessel, C.; Six, J. Organic and mineral input management to enhance crop productivity in central Kenya. Agron. J. 2009, 101, 1266-1275. [CrossRef]

34. Abera, G.; Wolde-meskel, E.; Bakken, L.R. Carbon and nitrogen mineralization dynamics in different soils of the tropics amended with legume residues and contrasting soil moisture contents. Biol. Fertil. Soils 2012, 48, 51-66. [CrossRef]

35. Abbasi, K.; Tahir, M.; Sabir, N.; Khurshid, M. Impact of the addition of different plant residues on nitrogen mineralization-immobilization turnover and carbon content of a soil incubated under laboratory conditions. Solid Earth 2015, 6, 197-205. [CrossRef] 
36. Mohanty, M.; Reddy, K.S.; Probert, M.E.; Dalal, R.C.; Rao, A.S.; Menzies, N.W. Modelling N mineralization from green manure and farmyard manure from a laboratory incubation study. Ecol. Model. 2011, 222, 719-726. [CrossRef]

37. Palm, C.A.; Gachengo, C.N.; Delve, R.J.; Cadisch, G.; Giller, K.E. Organic inputs for soil fertility management in tropical agro ecosystems: Application of an organic resource database. Agric. Ecosyst. Environ. 2001, 83, 27-42. [CrossRef]

38. Meyer, J.; Campbell, C.L.; Moser, T.; Hess, G.; Rawlings, J.; Peck, S.; Heck, W. Indicators of the Ecological Status of Agroecosystems. In Ecological Indicators; McKenzie, D.H., Hyatt, D.E., McDonald, V.J., Eds.; Elsevier: London, UK, 1990; pp. 629-658.

39. Barrios, E.; Herrera, R.; Valles, J.L. Tropical floodplain agroforestry systems in mid-Orinoco River basin, Venezuela. Agrofor. Syst. 1994, 28, 143-157. [CrossRef]

40. Barrios, E.; Trejo, M.T. Implications of local soil knowledge for integrated soil management in Latin America. Geoderma 2003, 111, 217-231. [CrossRef]

41. Menkir, A.; Chikoye, D.; Lum, F. Incorporating an herbicide resistance gene into tropical maize with inherent polygenic resistance to control Striga hermonthica (Del.) Benth. Plant Breed. 2010, 129, 385-392. [CrossRef]

42. Atera, E.A.; Ishii, T.; Onyango, J.C.; Itoh, K.; Azuma, T. Striga Infestation in Kenya: Status, Distribution and Management Options. Sustain. Agric. Res. 2013, 2, 99. [CrossRef]

43. Callaway, R.M.; Ridenour, W.M. Novel weapons: Invasive success and the evolution of increased competitive ability. Front. Ecol. Environ. 2004, 2, 436-443. [CrossRef]

44. Fujii, Y.H.S. Allelopathy: New Concepts \& Methodology, 1st ed.; Fujii, Y., Hiradate, S., Eds.; Science: Enfield, NH, USA, 2007.

45. Hagan, D.L.; Jose, S.; Lin, C. Allelopathic Exudates of Cogongrass (Imperata cylindrica): Implications for the Performance of Native Pine Savanna Plant Species in the Southeastern US. J. Chem. Ecol. 2013. [CrossRef] [PubMed]

46. Ayele, A.; Sharma, J.J.; Nigatu, L. The Impact of Commolina benghalensis Extract on Maize (Zea mays L.) Seed Germination and Early Seedling Growth. J. Biol. Agric. Heal. 2014, 4, 43-46.

47. Islam, A.K.M.M.; Ohno, O.; Suenaga, K.; Kato-noguchi, H. Suaveolic Acid: A Potent Phytotoxic Substance of Hyptis suaveolens. Sci. World J. 2014, 6. [CrossRef] [PubMed]

48. Paniagua, A.; Kammerbauer, J.; Avedillo, M.; Andrews, A.M. Relationship of soil characteristics to vegetation successions on a sequence of degraded and rehabilitated soils in Honduras. Agric. Ecosyst. Environ. 1999, 72, 215-225. [CrossRef]

49. Aganga, A.A.; Tshwenyane, S. Potentials of Guinea Grass (Panicum maximum) as Forage Crop in Livestock Production. Pakistan J. Nutr. 2004, 3, 1-4. [CrossRef]

50. Fay, J.M. Icacina oliviformis (Icacinaceae): A Close Look at an Underexploited Crop. I. Overview and Ethnobotany. Econ. Bot. 1987, 41, 512-522. [CrossRef]

51. Csurhes, S.; Hannan-Jones, M. Pest Plant Risk Assesment: Gamba Grass, Andropon gayanus; Queensland Government Department of Primary Industries and Fisheries: Mackay, Australia, 2008; p. 21.

52. Thrupp, C. Wetlands without Water: Managing Wetlands in the Semi-Arid Pastoral Zone of Western Queensland; World Wildlife Fund Australia, WWF: Sydney, Australia, 2003; p. 73.

53. Rossiter-Rachor, N.A.; Setterfield, S.A.; Douglas, M.M.; Hutley, L.B.; Cook, G.D. Andropogon gayanus (gamba grass) invasion increases fire-mediated nitrogen losses in the tropical savannas of northern Australia. Ecosystems 2008, 11,77-88. [CrossRef]

54. Isaac, W.-A.; Gao, Z.; Li, M. Managing Commelina species: Prospects and limitations. In Herbicides-Current Research and Case Studies in Use; Price, J.A., Kelton, A.J., Eds.; InTech: Rijeka, Croatia, 2013; pp. 543-561.

55. Fujisaka, S.; Fujisaka, S.; Escobar, G.; Escobar, G.; Veneklaas, E.J.; Veneklaas, E.J. Weedy fields and forests: Interactions between land use and the composition of plant communities in the Peruvian Amazon. Environment 2000, 78, 175-186. [CrossRef]

56. Murage, E.W.; Karanja, N.K.; Smithson, P.C.; Woomer, P.L. Diagnostic indicators of soil quality in productive and non-productive smallholders' fields of Kenya's Central Highlands. Agric. Ecosyst. Environ. 2000, 79, 1-8. [CrossRef]

57. Mairura, F.S.; Mugendi, D.N.; Mwanje, J.I.; Ramisch, J.J.; Mbugua, P.K.; Chianu, J.N. Integrating scientific and farmers' evaluation of soil quality indicators in Central Kenya. Geoderma 2007, 139, 134-143. [CrossRef] 
58. Aguirre, M.; Avilés, A.; Davis, W.; Domínguez, M. Identificación Y Validación De Indicadores Técnicos Y Locales De Calidad De Suelos En El Municipio De Nandaime. Recursos Naturales. La Calera 2011, 6, $13-17$.

59. Barrios, E.; Delve, R.J.; Bekunda, M.; Mowo, J.; Agunda, J.; Ramisch, J.; Trejo, M.T.; Thomas, R.J. Indicators of soil quality: A South-South development of a methodological guide for linking local and technical knowledge. Geoderma 2006, 135, 248-259. [CrossRef]

60. Nezomba, H.; Mtambanengwe, F.; Tittonell, P.; Mapfumo, P. Practical assessment of soil degradation on smallholder farmers' fields in Zimbabwe: Integrating local knowledge and scientific diagnostic indicators. Catena 2017, 156, 216-227. [CrossRef]

61. Wall, D.H.; Moore, J.C. Interactions Underground: Soil biodiversity, mutualism, and ecosystem processes. Bioscience 1999, 49, 109-117. [CrossRef]

62. Anderson, T.H. Microbial eco-physiological indicators to asses soil quality. Agric. Ecosyst. Environ. 2003, 98, 285-293. [CrossRef]

63. Orgiazzi, A.; Bardgett, R.; Barrios, E.; Behan-Pelletier, V.; Briones, M.; Chotte, J.; De Deyn, G.; Eggleton, P.; Fierer, N.; Fraser, T.; et al. Soil Biodiversity Atlas; European Commission, Publications Office of the European Union: Luxembourg, 2016; p. 176.

64. Gobin, A.; Campling, P.; Deckers, J.; Feyen, J. Integrated Toposequence Analyses to combine local and scientific knowledge systems. Geoderma 2000, 97, 103-123. [CrossRef]

65. Fleskens, L.; Jorritsma, F. A behavioral change perspective of maroon soil fertility management in traditional shifting cultivation in suriname. Hum. Ecol. 2010, 38, 217-236. [CrossRef] [PubMed]

66. Barrios, E.; Coutinho, H.L.C.; Medeiros, C.A.B. InPaC-S: Participatory Knowledge Integration on Indicators of Soil Quality, Methodological Guide; World Agroforestry Centre (ICRAF): Nairobi, Kenya; Embrapa: Nairobi, Kenya; Centro Internacional de Agricultura Tropical (CIAT): Nairobi, Kenya, 2012; p. 180.

67. Fosu-Mensah, B.Y.; Vlek, P.L.G.; MacCarthy, D.S. Farmers' perception and adaptation to climate change: A case study of Sekyedumase district in Ghana. Environ. Dev. Sustain. 2012, 14, 495-505. [CrossRef]

68. Banful, A.B. Operational Details of the 2008 Fertilizer Subsidy in Ghana; Preliminary Report; Ghana Strategy Support Program (GSSP), International Food Policy Research Institute (IFPRI): Washington, DC, USA, $2009 ;$ p. 38.

(C) 2018 by the authors. Licensee MDPI, Basel, Switzerland. This article is an open access article distributed under the terms and conditions of the Creative Commons Attribution (CC BY) license (http:/ / creativecommons.org/licenses/by/4.0/). 